\title{
Applying PLS-SEM in Investigating Factors Affecting Employee Engagement: The Case of SAS English Centre, Da Nang branch, Vietnam
}

\author{
Thi-Duong, Nguyen ${ }^{1 *}$, Thuy-Hai, Doan Thi ${ }^{1}$, Nhat-Quyet, Mai Thi ${ }^{2}$ \\ 1,2 The International School, Duy Tan University, Da Nang, Vietnam \\ *Corresponding's email: Nguyenthiduong1@dtu.edu.vn or duongyennguyen@gmail.com \\ ${ }^{1}$ First author's email: haidoan092019@gmail.com
}

\begin{abstract}
This stuy aims to explore the driven factors of employee engagement in the chain of English centre in Danang city, vietnam by applying PLS-SEM model. Eight variables were included in this study after the quanlitative research, in which employee engagement was the dependent variables, job satisfaction and organizational attention and support were hypothesied to have direct impact on employee engagement. Five other variables included Relationship in a workplace, Working environment, Job characteristics, Wage, Training and development were supposed to have influnce on employee engagement through intermediate variable-job satisfaction. The results of this study suppoted all research hypotheses. Additionally, five mentioned above variables were found to have no significant direct effect on employee engagement. This study results carries practical contribution to the management board, particularly to the human resources department of organization.
\end{abstract}

\section{Introduction}

Human resource plays a strategic role in the development of organization. Human resource is one of the important indicators of achieving organisational goals and help organization perform efficiently (Macke \& Genari, 2019). Organizations with powerful human resource were found to be more profitable compared to others. Since the administrators are aware of the importance of human resource, this sector has captured the great attention of not only the management board but also the researchers.

Employee engagement has long been regarded as one of the most important concepts in Human Resources. It was found that increasing employee engagement can definitely help organization to improve business performance and transform to the best (Cattermole et al., 2013). Employee engagement has been considered as the critical driver of business today as it can create a good working environment for employees, which affects their morale. Engagement also boosts the communication among employee, which assist them to complete their work effectively, from that increase working productivity (Altehrebah, 2019).

Engaged employees are being used as a strategic competence tool by businesses. Employees who are highly engaged continually have outperformance and create a new standard. Engaged employee plays a role of foundation line of any business in helping to improve their job performance, gain more customer loyalty, which in turn give organization more profit (Altehrebah, 2019).

In Vietnam, it is both important and challenging to develop the long-term human resource. The employee turnover rate has been on the rise in the last three years, reaching a rate of $24 \%$ in 2019 . The high turnover rate was caused partly by the fierce competition labour market. While accepting turnover as cost of doing business, Vietnams firm firms still strive to increase employee engagement as after consulting firms and surveying administrators, it was found that employee engagement can reduce turnover (Van \& Nafukho, 2019). Additionally, it can increase share shareholder value and as the catalyst for outperforming the competition. 
Employee engagement is one of the interest research field. Therefore, there is a need for academic research on this topic. This study aims to investigate the driven factors of employee engagement in the chain of English centre - SAS in Da Nang city, Vietnam. The following research objectives would facilitate the achievement of this goal: (1) review factors that positively affect employee engagement; (2) describe, analyse, and assess the situation of employee engagement in SAS English centre in Da Nang city; (3) infer and propose recommendations in terms of enhancing employee engagement.

\section{Literature Review}

\subsection{Definition of Employee Engagement}

Employee engagement with an organization has long been understood by many researchers and given different definitions. Employee engagement, according to Nguyen and Pham, (2016), employee engegement has three dimensions: emotional engagement (emotional attachment to one's work), cognitive engagement (striving at work), and physical engagement (showing a willingness to invest extra effort for the organizational development). Employee engagement is classified as either personal engagement, work engagement, or organizational engagement, which generates confusion.

According to Mowday et al. (2013), employee engagement with organization refered employee homogeneity, struggling, job satisfaction, and employee loyalty to the organization. This definition refers to the positive relationship between the employee and the organization that makes them always willing to put more effort to contribute to the success and development of the organization. Employee engagement, according to Saks (2019), is defined by employees' positive attitudes about the organization's ideals and actions. Employees who obtain appropriate physical and spiritual value from the organization feel obligated to repay them by giving their all to the organization. Employees are more optimistic and engaged, he claims, when the organization provides them with the resources they need. Gibbons (2006) defines the deep relationship that employees feel about their organization is employee engagement. According to Tella et al., (2007), engagement reflects job satisfaction and employee loyalty to the organization, and it is an ongoing process through which members show concern for the organization.

While there are many alternative definitions, experts believe that employee engagement is a vital notion in attempting to characterize the nature of the connection between a business, a work, and its employees in terms of both quality and quantity. An engaged employee is defined as someone who is willing to bring their best selves to work, is completely passionate and enthusiastic about it, has a positive attitude toward the organization and its values, and thus takes positive actions to improve personal performance, job efficiency, and the organization's reputation and benefits (Nguyen \& Pham, 2020).

\subsection{The Roles of Employee Engagement with Organization}

According to Saks \& Gruman (2014), employee involvement is critical to corporate success and competitiveness. Organizations are aware that using human capital can enhance their efficiency and competitive advantage. In other words, human resource is a means to increase the competitive advantage of an organization. The loss of employees, especially talented ones, means that the organization has to spend a lot of money, time and effort to recruit and train new replacement. This loss results in more losses than monetary damages because it has the potential to affect the will of those who remain.

Employee engagement is regarded as critical not only to individual performance but also to organizational success. It is described as a key determinant of individual attitudes, behaviors, and job satisfaction, as well as organizational cashflow, retention, productivity, 
shareholder return, and overall growth. According to Nguyen and Pham (2020), both managers and employees are concerned with the connection between employees and the workplace. We can visualize that there will be a link between the image of the organization and the personal image of the employee when employees feel like they want to engage with the organization. Therefore, managers must encourage employee engagement because if there is no engegement between the employee and the organization, the employee will not feel close and will not want to stick with the organization, ultimately resulting in the employee's tendency to leave the organization to find another good job.

\subsection{Driven Factors of Employee Engagement}

As mentioned, employee engagement has captured the great attention of organizations and reseachers. Many of studies were conducted aiming to find out the antecedents of employee engagement.

Kahn's structure proved to be one of the most useful. Psychological availability, psychological safety, and psychological meaningfulness are three psychological states that play a role as personal engagement components (Kahn, 1990). The results found by Task revealed that traits, job qualities, work interactions, interpersonal relationships, a stable and safe workplace, as well as leadership styles and team norms were determinants of employee engagement.

Dockel et al., (2006) investigated the influence of factors affecting the engagement of high-tech workers in telecommunications companies in Gauteng province, South Africa. The authors used 6 factors to measure employee satisfaction, including: superiors' support, Training and development opportunities, Promotion opportunities, Job characteristics, Wage and Welfare. They used a three-component scale for organizational engagement of Meyer and Allen including emotional engagement; for benefit and ethical linkage to measure the degree of employee's engagement with the organization. The results show that 4 factors: superiors' support, Job characteristics, Wage and Welfare has a strong influence on the organizational engagement of this high-tech worker, while the other 2 factors did not statistically influence employee engagement.

Job design, learning and development, performance management, and reward programs, according to Armstrong and Taylor (2014), should strengthen employee engagement in firms, while emphasizing the essential role of direct supervisors in promoting such organizational activities. Armstrong and Taylor (2014) advised that respecting employee, setting a meaningful and cultural climate and tackling the work environment systems can help to enhance employee engagement degree. The researchers believe that a work environment where employees are full of enthusiasm results in higher productivity. A coherent work environment makes employees feel like they want to work and want to be a part of the organization's success because their personal goals and organizational goals are closely linked. It will help the organization save a lot of tangible and intangible costs, time spent on recruiting and training new staff to replace.

The study of Ha Nam Khanh Giao and Nguyen Dang Huyen Tran (2017) on factors affecting employee's engagement was conducted to evaluate the influence staff engagement with the school by surveying 174 staff. Tools of Cronbach's Alpha, EFA and multiple regression analysis were used. The results have presented a 5-factor model that positively affects employee engagement, ranked in descending order: Job characteristics, Colleagues relationship, School reputation, Salary and welfare, Organizational support.

Margaretha et al., (2018) conducted a study on employee engagement and influencing factors in Indonesia. This study aimed to understand the factors that affect employee 
engagement of lecturers in Indonesia. Data collected from 200 respondents. Based on the results it was known that job characteristic, reward and recognition, perceived organizational and supervisor support affect employee engagement. Some managerial implications that can be applied based on the results of this study have been submitted in this research, one of those such as the organization should provide a challenging, safe and secure work environment for employees, in order to get proactive employees that will give a positive effect on overall organizational performance.

The results of a study conducted by Tran Van Dung in 2018 showed that the employee's engagement with the Company was affected by six independent factors ranked in order of importance are: Leadership style; Company culture; Income; Relationship with colleagues; The nature of work and Training and promotion opportunities and the mediating factor is Satisfaction.

Manivannan and Sanchita (2020) conducted the study "Factors influencing employee engagement in educational organization" in Chennai, India. In total a sample size of 689 was used to collect the valid responses using the research instrument in the form of a questionnaire with 5 factors: Rewards and Recognition for teachers, Job Contribution of teachers, employee Organizational Commitment, Perceived Organizational Support, as felt by teachers, and Teachers' Perceived Supervisor Support. The results show that all 5 predictor variables have significant impact on the outcome of interest. Further the maximum extent of impact seems to be from the perceived support from the employee supervisor followed by perceived job contribution while the rewards and recognition, while significant seems to have a lesser effect compared to other factors.

\section{Research Framework and Research Methods}

Previous studies have discovered many factors affecting the employee's connection with the organization in general, with businesses and companies in particular. However, there is not a common model for all types of businesses, but also depending on other conditions. In which the right conditions in Vietnam play an important role and that is also the basis for research. This study performed the assessment of the scale affecting the engagement of teachers and teaching assistants at SAS English Centre. Based on the above literature review, the authors proposed the below research model and hypotheses.

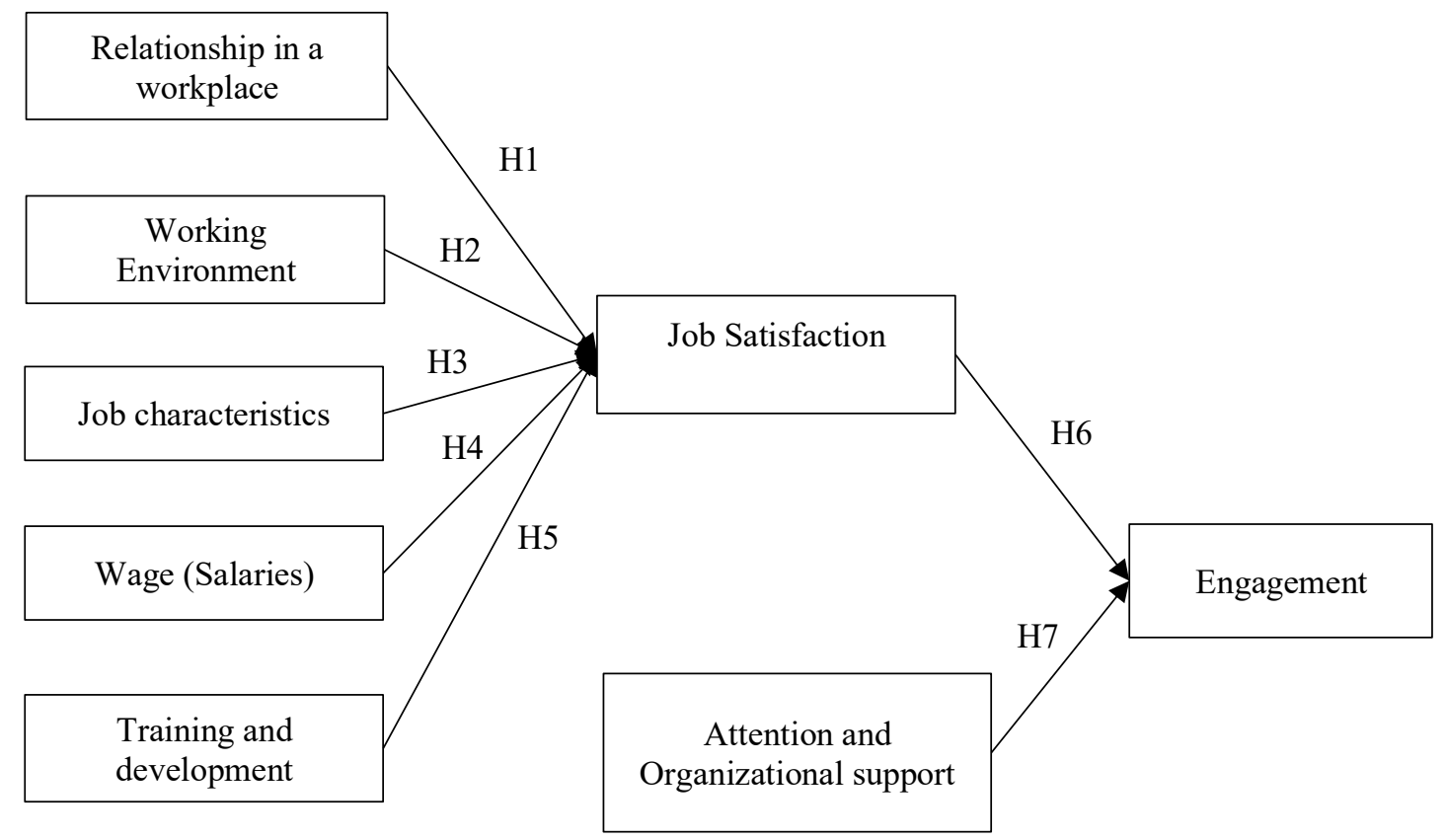


H1: Relationship in a workplace positively affects employee engagement through job satisfaction.

$\mathrm{H} 2$ : Working- Environment positively affects employee engagement through job satisfaction.

H3: Job characteristics positively affect employee engagement through job satisfaction.

H4: Wage (Salaries) positively affects employee engagement through job satisfaction.

H5: Training and development positively affect employee engagement through job satisfaction.

H6: Job satisfaction positively affects employee engagement.

H7: Attention and Organizational positively affects employee engagement.

\subsection{Research methods}

In search of a topic, the author proposes a research model that includes 6 independent variables: Relationship in a workplace, working environment, job characteristics, wage (Salaries), training and development, attention and organizational support, one intermediate variable is job satisfaction, and the dependent variable is the engagement of teachers and teaching assistants at SAS centres in Da Nang city.

\subsubsection{Qualitative research}

Qualitative research is done to check whether the factors and observed variables are consistent with the current situation of the SAS English centre in Da Nang, or whether such factors and variables should be removed. Or whether there will need to be additions to any observed variables or not. After that, the author will use these results to set up a questionnaire for quantitative research.

The research design used in qualitative research is a structured interview. The authors conducted a discussion with 7 individuals working in the management department at SAS Da Nang English Centre, of which 3 are experts at the human resources (HR) department, the rest are in the facility management department. The content of this interview was fully and carefully recorded, synthesized as a basis for the correct adjustment and supplement of the scale content to prepare for the next official investigation phase.

The results can be summarized after discussion. In general, the comments of experts on factors affecting the job satisfaction of teachers and teaching assistants revolve around working environment factors, relationships in a workplace, working environment, salary, training and development policy of the company. This is consistent with the proposed theoretical basis and research model.

Regarding factors affecting the engagement of teachers and teaching assistants: Through interviews, we can see the factors that businesses care about and support (concerns about interests, aspirations, opinion, assistance for teachers or teaching assistants with challenges) and job satisfaction (work environment, co-worker relationships; leadership, nature of work, wages, training and development policies of the company, etc) are factors affecting engagement. These are also the two main factors affecting the engagement mentioned in the theoretical basis and the proposed research model. Commenting on observed variables and measuring the proposed variables in the model, interviewed experts think that most of the variables reflect the investigation objectives.

\subsubsection{Quantitative Research}


The authors have conducted quantitative research to look for the answers for the relationship between independent variables and employee engagement in the proposed research model. Quantitative research is conducted as soon as the questionnaire is revised from qualitative research results, which makes a total of 33 questions. In Based on this, a questionnaire has been sent in the form of soft copies to teachers and teaching assistants of SAS centre.

In this study, the simple random sampling method is used. To analyze the relationship between engagement, factors for job satisfaction, attention and organizational support, methods Linear structural analysis (SEM) is used. This method requires a large sample size because it is based on the theory of sample distribution (Raykov and Widaman 1995). However, according to Hair et al. (1998) if the Maximum Likelihood estimation method, the minimum sample size from 100 - 150. In addition, the sample size for the estimated method used in the linear structure model (SEM) has three types: small sample $\leq 100$, average sample $100-200$ and large sample $\geq 200$. The sample size of this study is 125 , so basically it is satisfied requirement of analytical method.

\section{Empirical Results}

\subsection{Sample Descriptive Statistics}

Total 125 questionnaires were collected. After collecting all the data from respondents, these questionnaires were tested carefully to ensure strictly about the reliability and validity in analysis. The result presented that there are 119 appropriate questionnaires, which means that $95.2 \%$ out of total collected questionnaires are information of the subject included: age, gender, marital status, academic level, occupation, experience years in the part one of the questionnaires; questions about respondent's experience of engagement in the second part of the survey questionnaires

Table 1: Sample descriptive statistics

\begin{tabular}{|c|c|c|c|}
\hline \multirow{3}{*}{ Age } & Items & Frequency & Percent \\
\hline \multirow{3}{*}{ Gender } & $18-25$ & 35 & 29.4 \\
\cline { 2 - 4 } & $26-35$ & 67 & 56.3 \\
\cline { 2 - 4 } & $>36$ & 17 & 14.3 \\
\cline { 2 - 4 } & Male & 44 & 37 \\
\hline \multirow{2}{*}{ Marital status } & Female & 75 & 63 \\
\cline { 2 - 4 } & Single & 80 & 67.2 \\
\hline \multirow{2}{*}{ Job position } & Married & 39 & 32.8 \\
\hline \multirow{3}{*}{ Academic level } & Teacher & 43 & 61.3 \\
\cline { 2 - 4 } & Teaching assistant & 38.7 \\
\cline { 2 - 4 } & Teaching certificate (Tesol, Tefl) & 43 & 36.1 \\
\cline { 2 - 4 } & Intermedia & 1 & 0.8 \\
\cline { 2 - 4 } & College & 12 & 10.1 \\
\hline \multirow{3}{*}{$\begin{array}{c}\text { Working } \\
\text { experience }\end{array}$} & University & 59 & 49.6 \\
\cline { 2 - 4 } & Master & 58 & 3.4 \\
\cline { 2 - 4 } & $1-3$ years & 20 & 32.7 \\
\cline { 2 - 4 } & 3- 6 years & $\mathbf{1 1 9}$ & 16.8 \\
\hline Total & 6-10 years & & $\mathbf{1 0 0}$ \\
\hline
\end{tabular}




\subsection{Reliability Test - Cronbach's Alpha}

In this section, Cronbach's alpha which is a model of internal consistency, based on the average inter-item correlation was calculated in this part to confirm that all items were measuring the same construct.

Table 2: Reliability Test - Cronbach's Alpha

\begin{tabular}{|l|l|}
\hline & Cronbach's Alpha \\
\hline Attention and Organizational support & 0.904 \\
\hline Engagement & 0.937 \\
\hline Job characteristic & 0.877 \\
\hline Job satisfaction & 0.876 \\
\hline Relationship in a workplace & 0.930 \\
\hline Training and Development & 0.930 \\
\hline Wage (Salaries) & 0.864 \\
\hline Working environment & 0.935 \\
\hline
\end{tabular}

The results of this analysis step are showed in the following table 4.7. Table 4.7 indicated that Cronbach's alpha for all variables were higher than 0.7 (Nunnally, J.C. 1978), which means that the internal consistency reliability of all variables is acceptable. Therefore, all variables of this study are suitable for next analysis.

\subsection{Convergent Validity}

Convergent validity is assessed through three components: Composite reliability, the average variance extracted (AVE) and the outer loading.

Composite reliability (CR) is a measure of scale reliability, which is used assesses the internal consistency of a measure. According to Hair et al (2017), the aggregated reliability coefficient is from 0.7 or more, so that the factors have internal consistency.

The average variance extracted (AVE) is a measure to assess convergent validity. This measure is similar to explained variance in EFA in SPSS. AVE presents the average amount of variance in indicator variables that a construct is managed to explain. AVE must be greater than 0.5 (Hair et al 2017) to be acceptable. If the average variance extracted is less than .50, then the variance due to measurement error is greater than the variance due to the construct. In this case, the convergent validity of the construct is questionable.

The outer loading index is used to measure the reliability of the scale. The scales with factor load coefficients of less than 0.4 should be removed from the research model. Scales with strong factor load coefficients $(\geq 0.7)$ should be retained in the research model. For scales with factor load factors between 0.4 and less than 0.7 , rejection of the scale can only be performed if the elimination increases the value of the combined confidence factor or the mean extracted variance. (Bagozzi et al 1991; hair et al 2011).

The results summarized in Table 3 showed that composite reliability of all variables was greater than 0.7 and the average variance extracted (AVE) of all variables was higher than 0.5 . Figure 1 reported the factor loading of all 33 observed sub-scale. As showed at figure 1, all factor loadings were greater than 0.7 . Therefore, it was concluded that all variables in this study were valid. 
Table 3. Composite Reliability and Average Variance Extracted (EVA)

\begin{tabular}{|c|c|c|}
\hline & Composite Reliability & $\begin{array}{c}\text { Average Variance } \\
\text { Extracted (AVE) }\end{array}$ \\
\hline Attention and Organizational support & 0.928 & 0.722 \\
\hline Engagement & 0.952 & 0.799 \\
\hline Job Characteristics & 0.924 & 0.802 \\
\hline Job satisfaction & 0.924 & 0.801 \\
\hline Relationship in a workplace & 0.947 & 0.781 \\
\hline Training and Development & 0.950 & 0.826 \\
\hline Wage (salaries) & 0.917 & 0.787 \\
\hline Working Environment & 0.950 & 0.793 \\
\hline
\end{tabular}

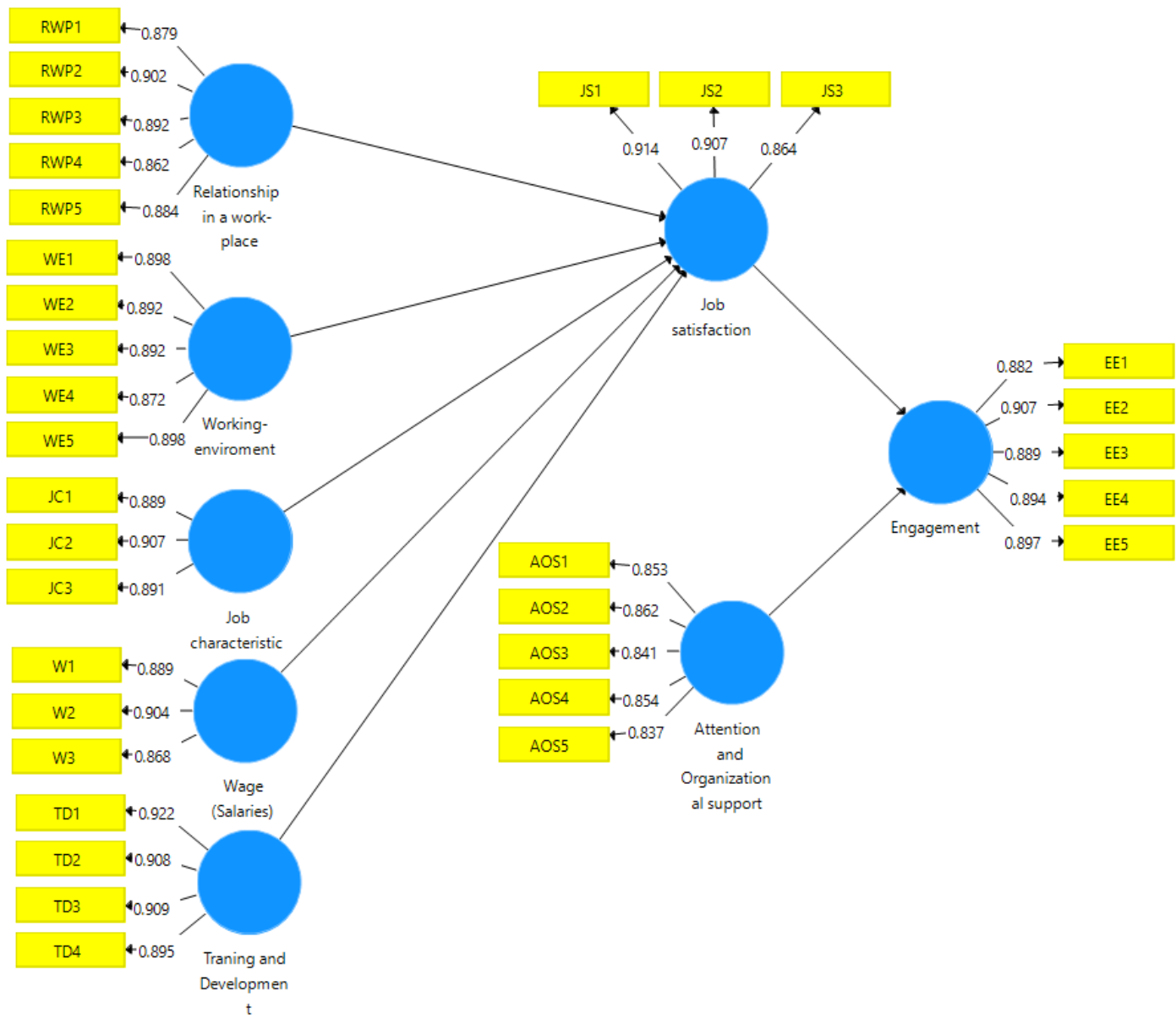

Figure 1: Outer loading

\subsection{Structure model evaluation}

Standardized root mean square residual (SRMR) should be considered to verify the model fit. According to $\mathrm{Hu}$ and Bentler (1999), the SRMR must be less than 0.08 or 0.1. 
Table 4: Verify the model fit

\begin{tabular}{|c|c|c|}
\hline & Saturated Model & Estimated Model \\
\hline SRMR & 0.038 & 0.039 \\
\hline
\end{tabular}

Thus, with the value of SRMR $=0.038<0.08$, the research model is concluded consistent with the study area at the SAS English center, Da Nang branch.

The value of $R^{2}$ varies from 0 to 1 , the higher the value, the higher the value, which proves the accuracy in the model prediction.

Table 5: R square

\begin{tabular}{|c|c|c|}
\hline & R Square & R Square Adjusted \\
\hline Engagement & 0.930 & 0.928 \\
\hline Job satisfaction & 0.944 & 0.941 \\
\hline
\end{tabular}

The analytical results show that the adjusted $R^{2}$ value of the engagement model is 0.930 and the adjusted $R^{2}$ value of the job satisfaction model is 0.944 , meeting the model's statistical standards.

Use Cohen's impact measurement, known as the $f^{2}$ impact factor. Cohen (1988) gave a test for the value of $f^{2}=0.02$ showing "small impact", the coefficient 0.15 (average impact) and 0.35 (big impact) of the external structure on an endogenous structure.

Table 6: F square

\begin{tabular}{|c|c|c|c|}
\hline & Engagement & Job satisfaction & $\begin{array}{c}\text { Influence } \\
\text { level }\end{array}$ \\
\hline Attention and Organizational support & 0.115 & & Small impact \\
\hline Job satisfaction & 2.687 & & Great impact \\
\hline Job Characteristics & & 0.066 & Small impact \\
\hline Relationship in a workplace & & 0.134 & Small impact \\
\hline Training and Development & & 0.114 & Small impact \\
\hline Wage (salaries) & & 0.068 & Small impact \\
\hline Working Environment & & 0.114 & Small impact \\
\hline
\end{tabular}

Thus, through the model, we can conclude that the Job satisfaction have a great impact on the Engagement with $f^{2}=2.687$.

\subsection{Hypotheses Testing by Bootstrapping}

In order to be able to extrapolate research results overall, the model should be tested for reliability. The thesis used the bootstrapping technique with a repeat sample size of 500 observations $(n=500)$ with an initial sample size of 119 samples. Estimation results from 500 observed samples show that the base weight is significant with the mean of bootstrapping because all weights are within the $95 \%$ confidence interval. Thus, the estimates in the model can be concluded to be reliable.

As mentioned, the topic has 7 necessary hypotheses tested. Results of estimating relationship between research concepts shows 5 out of total 5 factors affecting satisfaction at 
the significant level 5\% statistic because all 5 factors have T-value coefficient $>1.96$. Two factors-Job satisfaction and factor attention and organizational support significantly affect the engagement with T-value $>1.96$ and $p<5 \%$. The hypotheses are detailed in Table 7 .

Table 7. Hypotheses Testing by Bootstrapping

\begin{tabular}{|c|c|c|c|c|c|c|}
\hline 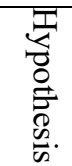 & Relationship & $\begin{array}{c}\text { Original } \\
\text { Sample }(O)\end{array}$ & $\begin{array}{c}\text { Sample } \\
\text { Mean (M) }\end{array}$ & $\begin{array}{l}\text { Standard } \\
\text { Deviation }\end{array}$ & T Statistics & $\mathrm{P}$ \\
\hline H1 & $\begin{array}{l}\text { Relationship in a workplace -> } \\
\text { Job satisfaction }\end{array}$ & 0.277 & 0.286 & 0.085 & 3.263 & 0.001 \\
\hline $\mathrm{H} 2$ & $\begin{array}{l}\text { Working Environment -> Job } \\
\text { satisfaction }\end{array}$ & 0.239 & 0.235 & 0.075 & 3.169 & 0.002 \\
\hline $\mathrm{H} 3$ & 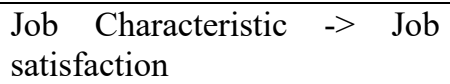 & 0.147 & 0.145 & 0.066 & 2.217 & 0.027 \\
\hline H4 & $\begin{array}{lll}\text { Wage (Salaries) } & -> & \text { Job } \\
\text { satisfaction } & & \\
\end{array}$ & 0.186 & 0.180 & 0.057 & 3.278 & 0.001 \\
\hline H5 & $\begin{array}{l}\text { Training and Development }> \\
\text { Job satisfaction }\end{array}$ & 0.170 & 0.171 & 0.051 & 3.366 & 0.001 \\
\hline H6 & $\begin{array}{l}\text { Job satisfaction } \quad-> \\
\text { Engagement }\end{array}$ & 0.352 & 0.350 & 0.096 & 3.660 & 0.000 \\
\hline $\mathrm{H} 7$ & $\begin{array}{l}\text { Attention and Organizational } \\
\text { support }->\text { Engagement }\end{array}$ & 0.169 & 0.167 & 0.050 & 3.378 & 0.001 \\
\hline
\end{tabular}

The author also run the bootstraping to test wether there are direct relationships between 5 independent factors (Relationship in a workplace, Job Characteristics, Working environment, Wage, Training and Devenlopment) with employee engagement. The results of this second bootstraping will support the acceptances of hypothesis 1 to hypothesis 5 .

The results of the second bootstraping are presented in Table 8.

Table 8: Testing direct relationship by bootstraping

\begin{tabular}{|l|c|c|c|c|c|}
\hline \multicolumn{1}{|c|}{ Relationship } & $\begin{array}{c}\text { Original } \\
\text { Sample (O) }\end{array}$ & $\begin{array}{c}\text { Sample } \\
\text { Mean (M) }\end{array}$ & $\begin{array}{c}\text { Standard } \\
\text { Deviation }\end{array}$ & T Statistics & P Values \\
\hline $\begin{array}{l}\text { Relationship in a workplace > } \\
\text { Engagement }\end{array}$ & 0.130 & 0.135 & 0.088 & 1.472 & 0.142 \\
\hline $\begin{array}{l}\text { Working Environment -> } \\
\text { Engagement }\end{array}$ & 0.118 & 0.112 & 0.075 & 1.562 & 0.119 \\
\hline Job Characteristic -> Engagement & 0.019 & 0.023 & 0.071 & 0.275 & 0.783 \\
\hline $\begin{array}{l}\text { Wage (Salaries) -> Engagement } \\
\text { Training and Development }>\end{array}$ & 0.132 & 0.129 & 0.075 & 1.760 & 0.079 \\
\hline Engagement & 0.102 & 0.106 & 0.052 & 1.953 & 0.051 \\
\hline
\end{tabular}

As indicated in Table 8, all five observed factors do not have the direct impact on employee engagement. However, they were found to have direct influence on job satisfaction and job satisfaction significantly affects employee engagement. Therefore, we once again, conclude that job satisfaction mediate the relationship of these five observed factors with engagement. 
Figure 2 show the resultsof bootstrapping

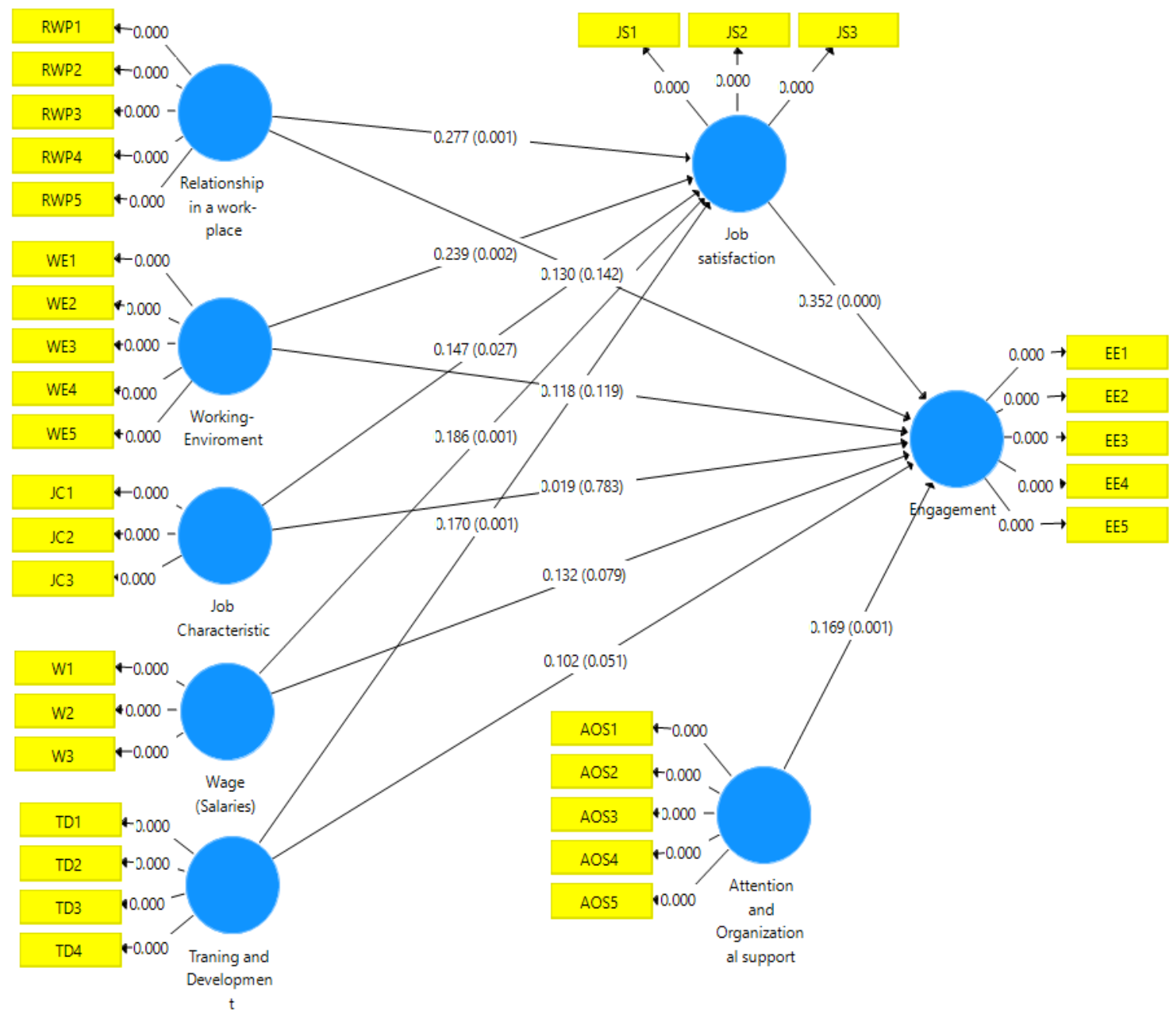

Figure 2: Path Coefficients and p-value

\section{Conclusions}

With the aim of examining the research models of employee engagement in general and teachers and teaching assistants in particular, the authors have drawn and proposed 7 factors that affect the engagement of teachers and teaching assistants and applied to this study, including: Attention and Organizational support, Job satisfaction, Job Characteristics, Relationship in a workplace, Training and Development, Wage (salaries), Working Environment.

From the definitions and related studies, the author builds a research model that measures the attachment of teachers and teaching assistants to the above factors with a total of 38 observed variables for the 8 model factors above.

The research is conducted through two methods, qualitative research conducted by structured interviews with a group of individuals having experience in the company. The result 
of the qualitative study resulted in 8 factors with total 33 observed variables. Quantitative research is conducted after summarizing the results from qualitative research, then conducting a survey by distributing questionnaires directly to 125 employees working at SAS English centre, Da Nang branch.

The results of practical testing of factors affecting the engagement of teachers and teaching assistants of SAS English centre, Da Nang branch showed that job satisfaction and attention and organizational support are two factors that directly influnce the engagement of employee while the relationships of five factors - relationship in a workplace, bob Characteristics, working environment, wage, training and devenlopment with employee engagement were mediated by job satisfaction. Or in the other words, job satisfaction plays as the intermediate variables between these five factors and engagement.

Like every other study, this research has its limitations such as it forcused limitedly to the SAS English centre with a branch in Da Nang, so this study cannot answer the general engagement of teachers and teaching assistants in the coastal areas. Central Coast or the entire territory of Vietnam. Thus, future research should expand the scope of research. Secondly, due to the limited research time, the author only conducted interviews with a relatively small number of samples, so it did not completely reflect the factors that create the connection of teachers and teaching assistants. Therefore, it is advisable to conduct studies over long periods of time and repeat to evaluate the Trend of change for improvement or failure.

\section{References}

Macke, J., \& Genari, D. (2019). Systematic literature review on sustainable human resource management. Journal of cleaner production, 208, 806-815.

Altehrebah, S. S. A. S. (2019). Factors influencing employee engagement: a study of Sana'a University (Doctoral dissertation, University Utara Malaysia).

Cattermole, G., Johnson, J., \& Roberts, K. (2013). Employee Engagement Welcomes the Dawn of an Empowerment Culture. Strategic HR Review, 12 (5), 250-254

Van, H. T. M., \& Nafukho, F. M. (2019). Employee engagement antecedents and consequences in Vietnamese businesses. European Journal of Training and Development.

NGUYEN, L. G. T., \& PHAM, H. T. (2020). Factors affecting employee engagement at notfor-profit organizations: A case in Vietnam. The Journal of Asian Finance, Economics, and Business, 7(8), 495-507.

Mowday, R. T., Porter, L. W., \& Steers, R. M. (2013). Employee-organization linkages: The psychology of commitment, absenteeism, and turnover. Academic press.

Saks, A. M. (2019). Antecedents and consequences of employee engagement revisited. Journal of Organizational Effectiveness: People and Performance.

Gibbons, J. M. (2006). Employee engagement: A review of current research and its implications. New York, NY: The Conference Board.

Tella, A., Ayeni, C. O., \& Popoola, S. O. (2007). Work motivation, job satisfaction, and organisational commitment of library personnel in academic and research libraries in Oyo State, Nigeria. Library philosophy and practice, 9(2).

Saks, A. M., \& Gruman, J. A. (2014). What do we really know about employee engagement?. Human resource development quarterly, 25(2), 155-182. 
Kahn, W. A. (1990). Psychological conditions of personal engagement and disengagement at work. Academy of management journal, 33(4), 692-724.

Dockel, A., Basson, J. S., \& Coetzee, M. (2006). The effect of retention factors on organisational commitment: An investigation of high technology employees. SA Journal of Human Resource Management, 4(2), 20-28.

Armstrong, M., \& Taylor, S. (2014). Armstrong's handbook of human resource management practice.

Giao, H. N. K., \& Tran, N. D. H. (2017). Factor affecing the (No. nswz6). Center for Open Science.

Margaretha, M., Widiastuti, R., Zaniarti, S., \& Wijaya, H. (2018). Employee Engagement and Factors that Influence: Experiences of Lecturers in Indonesia. International Journal of Management Science and Business Administration, 4(6), 34-41.

NGUYEN, H. M., NGUYEN, C., NGO, T. T., \& NGUYEN, L. V. (2019). The effects of job crafting on work engagement and work performance: A study of vietnamese commercial banks. The Journal of Asian Finance, Economics, and Business, 6(2), 189-201.

Raykov, T., \& Widaman, K. F. (1995). Issues in applied structural equation modeling research. Structural Equation Modeling: A Multidisciplinary Journal, 2(4), 289-318. 